\title{
Reproductive potential and developmental stages of Bandicota indica from four villages in four Townships in Magway Region, Myanmar
}

\begin{abstract}
Reproductive potential and development stages of Bandicota indica were studied in Magway Township, Minbu (Sagu) Township, Pwintbyu Township and Kamma Township, Magway Region during the period from January to December 2017. These townships were more productive area of rice and legumes in Magway Region. B. indica appeared as the dominant species in study area and a serious pest in agriculture fields and importance to next the insect pests. Rats were caught by laying traps near the entrance of rat holes and along the prospective travel routes within the crop fields. A total of 288 rats were captured, consisting of 157 males and 131 females. The number of male rat was somehow more than the number of female rat in all four study sites but the sex ratio did not differ significantly from a 1:1 ratio. The highest number of $B$. indica was found in November and December during the harvesting stages of the rice as peak population of rodents in the field depended on the available food and shelter. Breeding activity was more pronounced during the growing and harvesting stages than during the fallow period. Since rodents are the major cause of heavy damage in cultivated field, there is a need to outline effective measures in order to prevent the onslaught of rodents on the crops in order to safeguard the harvest yield.
\end{abstract}

Volume 4 Issue I - 2019

\author{
Aye Yu San, ${ }^{1}$ Mie Mie Sein² \\ 'Department of Zoology, Magway University, Myanmar \\ 2Mawlamyine University, Myanmar
}

Correspondence: Aye Yu San, Assistant Lecturer, Department of Zoology, Magway University, Myanmar.

Email ayeyusan022@gmail.com

Received: December 17, 2018 | Published: January 21, 2019

Keywords: Bandicota indica, reproduction, sex ratio, crop field

\section{Introduction}

The rodents represent $43 \%$ of species diversity within the class Mammalia are recognized by Wilson and Reeder. ${ }^{1}$ Approximately 20 species of rodents have been recorded in Myanmar. ${ }^{1}$ Rodents represent major pest problems worldwide, both in the countryside and in the cities. They do, for instance, cause serious damage to crops (such as cereals, root crops, cotton and sugarcane) both before and after harvest. ${ }^{3}$ Rodents typically have short gestation period, with high litter sizes and ability to become full pregnant again after a few days of delivery. These factors alone would ensure a high reproductive potential. However, many rodents also attain sexual maturity at very early ages, due mainly to rapid growth during the first few weeks of life. ${ }^{2}$ Rodents cause severe damage to various crops both directly and indirectly by gnawing, spoilage, contamination and hoarding activities. Rodents can adjust to the cropping system, establishing during the initial period of the crop, breeding during crop growing period, capable of rapid population growth and emigration after crop harvest depending upon food availability. ${ }^{4}$ The effect of rodent's damage cause huge amount of losses and food shortages in some parts of the world. ${ }^{5}$ Myanmar is an agricultural country and rice, maize, oilseed, sugarcane, and pulses are the main crops. Agriculture is one of the most important sectors of Myanmar's economy. ${ }^{6}$ Most rodents are agricultural pests, therefore the knowledge of their reproductive activities is necessary to control pest effectively and very important to understand abundance changes of rats and mice in specific cropping systems.

Thus, the present study was conducted with the following objectives:

i. To investigate the reproductive potential of Bandicota indica in the study areas.

ii. To assess the developmental stages of $B$. indic.

\section{Materials and methods}

\section{Study area}

Four Townships which are noted for the abundance of cultivation and rats were allocated for the study included Magway, Minbu (Sagu), Pwintbyu and Kamma (Figure 1).

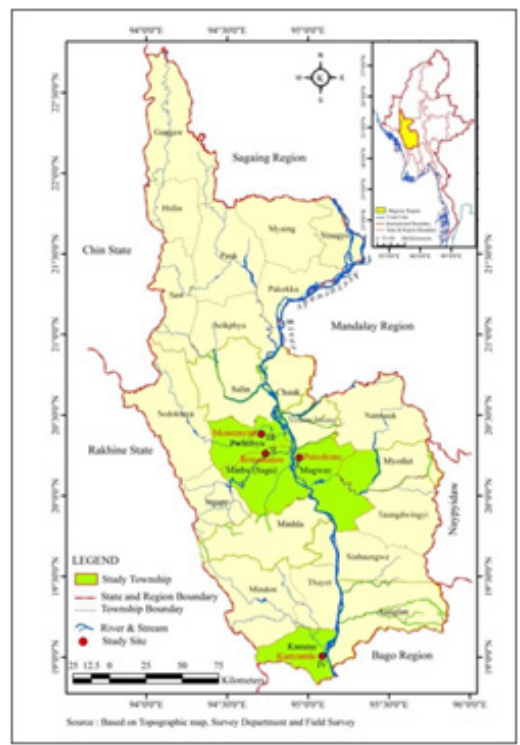

Figure I Map of Magway region.

Sites I: Puteekone village in Magway Township is situated between $20^{\circ} 14^{\prime} 39.9^{\prime \prime} \mathrm{N}$ and $94^{\circ} 56^{\prime} 23.9^{\prime \prime} \mathrm{E}$.

Site II: Bonemanoe village of Minbu (Sagu) Township is located between $20^{\circ} 15^{\prime} 27.02^{\prime \prime} \mathrm{N}$ and $94^{\circ} 43^{\prime} 48.506^{\prime \prime} \mathrm{E}$. 
Site III: Monemyint village of Pwintbyu Township is between $20^{\circ} 22^{\prime}$ $58.626^{\prime \prime} \mathrm{N}$ and $94^{\circ} 42^{\prime} 30.339^{\prime \prime} \mathrm{E}$

Site IV: Kanyintile village of Kamma Township is situated between $19^{\circ}$ 00' 20.709" $\mathrm{N}$ and $95^{\circ} 05^{\prime} 16.351^{\prime \prime} \mathrm{E}$.

Study period: The study was conducted from January to December, 2017.

\section{Sampling procedures}

Monthly trappings lasted for three consecutive nights per set in the four sampling locations. A total of 50 traps were placed around the sampling sites each night, and usually placed near rat holes, and in areas that included potential travel routes of the rats. The traps were mostly placed in the agricultural lands. The traps were set in the evening and collected the next morning at sun rise. Captured rats were recorded and identified individually, sexed, weight, length of tail, ear, hind foot (without claw) and head plus body.

\section{Rate of reproduction}

The number of young produced per female per season per year of reproduction was computed following equation by Southwick (1996). ${ }^{7}$

$$
\mathrm{F}=\mathrm{P}(\mathrm{t} / \mathrm{v})
$$

$\mathrm{F}=$ incidence of pregnancy

$\mathrm{P}=$ prevalence of pregnancy

$\mathrm{t}=$ sampling time in days that is, the period of time during which a population has been producing young $\mathrm{v}=$ time in days of gestation during which pregnancy is macroscopically visible Rate of reproduction $=$

Incidence of pregnancy $\times$ embryonic litter size (Figure 1).

\section{Results}

\section{Reproductive Potential of Bandicota indica}

Sex ratio: Total 288 rats were trapped three consecutive nights in each month from January to December. Out of these, 157 were males and 131 females. According to sex ratio, numbers of female rats were more than male during the month of March and July. The sex ratio 1:1 was investigated in April and November. The male rats were found slightly higher in number than female rats in the remaining months.

The seasonal sex ratio of $B$. indica, 32 male rats and 31 female rats , a ratio of 1:0.97 but the observation are not significantly difference $\left(\chi^{2}\right.$ $=1.19 ; \mathrm{p}>0.05)$ in hot season. The male 61 and female 45 were found and the sex ratio 1:0.69, also was not significant difference $\left(\chi^{2}=3.2\right.$; $\mathrm{p}>0.05$ ) in rainy season. In cold season, 64 male rats and 55 female rats, sex ratio 1:0.86, also revealed no significant difference $\left(\chi^{2}=2.46\right.$; $\mathrm{p}>0.05$ ).

Rate of reproduction: The numbers of embryo consist in two elongate uterine horns, were investigated base on 42 pregnant females and revealed that in the right uterine horn, maximum number of mean embryo was $4.77 \pm 1.53$ and the minimum $3.5 \pm 0.96$. In the left uterine horn, maximum number of mean embryo was $3.85 \pm 0.77$ and the minimum was $2.6 \pm 0.47$. The right uterine horn harboured more embryo than left uterine horn (Table 1).

Table I Mean number of embryos encountered in the right and left uterine horns of pregnant female Bandicota indica

\begin{tabular}{lllll}
\hline Site & $\begin{array}{l}\text { Number of } \\
\text { pregnant female }\end{array}$ & $\begin{array}{l}\text { Mean number of } \\
\text { embryo right horn }\end{array}$ & $\begin{array}{l}\text { Mean number of } \\
\text { embryo left horn }\end{array}$ & $\begin{array}{l}\text { Total numbers of } \\
\text { embryo observed }\end{array}$ \\
\hline I & 6 & $(3.5 \pm 0.96)$ & $(2.6 \pm 0.47)$ & $(6.17 \pm 0.69)$ \\
II & 14 & $(3.5 \pm 1.35)$ & $(3.29 \pm 0.80)$ & $(6.79 \pm 1.52)$ \\
III & 9 & $(3.78 \pm 1.13)$ & $(3.44 \pm 0.96)$ & $(7.22 \pm 1.55)$ \\
IV & 13 & $(4.77 \pm 1.53)$ & $(3.85 \pm 0.77)$ & $(8.62 \pm 1.86)$ \\
\hline
\end{tabular}

More pregnant rats were found in rainy season than hot and cold season. The prevalence of pregnancy $(\mathrm{P}=0.576)$ and incidence of pregnancy $(\mathrm{F}=2.16)$ were observed highest in rainy season. Minimum prevalence of pregnancy $(\mathrm{P}=0.259)$ and incidence of pregnancy
$(\mathrm{F}=0.97)$ were observed in hot season. The seasonal production of the young was high in rainy season (14.90 young/ female/ season) and the least in hot season (6.49young/female/season) (Table 2).

Table 2 Seasonal phases of reproduction in the samples of Bandicota indica collected during January and December, 2017

\begin{tabular}{llllll}
\hline Seasonal & $\begin{array}{l}\text { Adult females } \\
\text { (Preg. females) }\end{array}$ & $\begin{array}{l}\text { Prevalence of } \\
\text { pregnancy, } \mathbf{P}\end{array}$ & $\begin{array}{l}\text { Embryonic } \\
\text { litter size } \mathbf{X} \pm \mathbf{S E}\end{array}$ & $\begin{array}{l}\text { Incidence of } \\
\text { pregnancy, } \mathbf{F}\end{array}$ & $\begin{array}{l}\text { No. of young } \\
\text { females }\end{array}$ \\
\hline Hot season & $27(7)$ & 0.259 & $6.7 \pm 1.278$ & 0.97 & 6.49 \\
Rainy season & $33(19)$ & 0.576 & $6.9 \pm 1.774$ & 2.16 & 14.9 \\
Cool season & $40(16)$ & 0.400 & $8.2 \pm 1.704$ & 1.5 & 12.3 \\
\hline
\end{tabular}

\section{Development of Bandicota indica}

The gestation period is categorized into three intervals called trimester based on 42 pregnant females' samples.

Trimester 1(T1): The duration of trimester 1 was ranged from 7-8 days. In early stage of $\mathrm{T} 1$, the embryonic bulges were prominent to be measured (Figure $2 \mathrm{~A}$ ). In late stage of T1, the series of distinct bulges become obvious in two uterine horns. The measurements of the bulges ranged from 2-10 $\mathrm{mm}$ in diameter (Figure $2 \mathrm{~B}$ ).

Trimester 2 (T2): The duration of trimester 2 ranged from 7-8 days. In early stage of $\mathrm{T} 2$, the embryo marked by nervous, circulatory and alimentary system. The back bone is distinct (Figure $2 \mathrm{C}$ ). In late stage of T2, the initial stage of eyes and ears are appeared. Limbs appeared like buds. The umbilical cord connected between uterine wall and embryos became more prominent. The length of embryo ranged from 11-16 mm (Figure 2 D). 


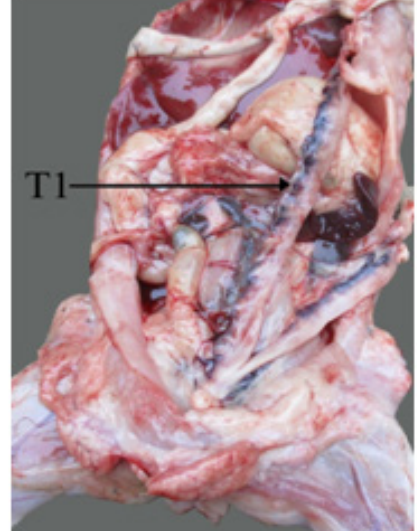

A.

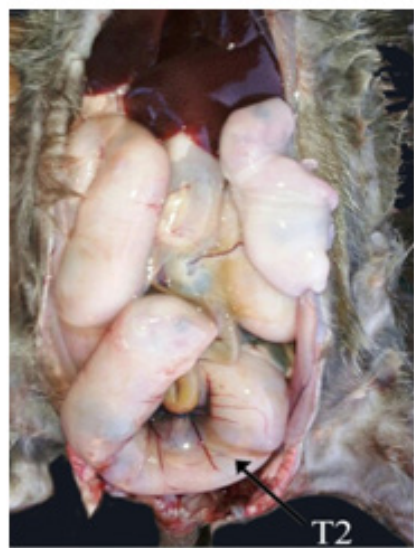

Late trimester

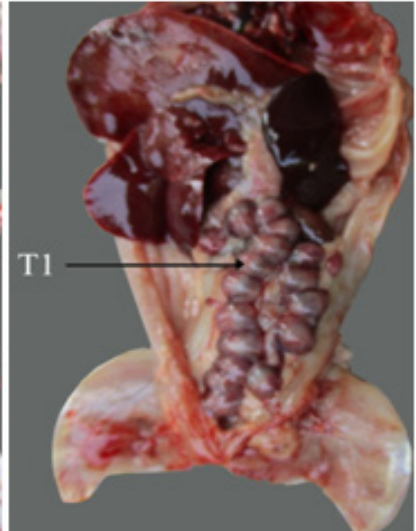

B. Late trimester

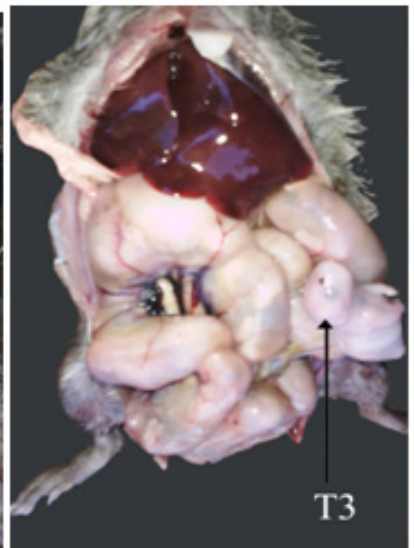

E. Early trimester

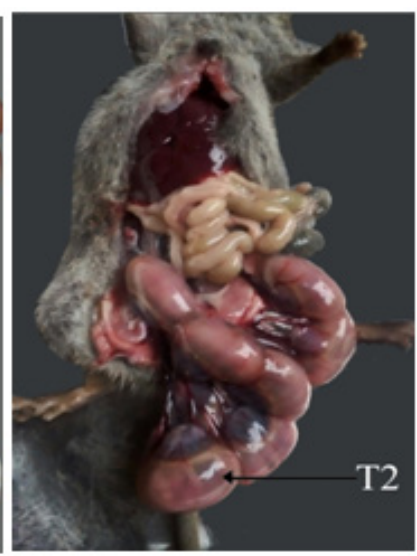

C. Early trimester

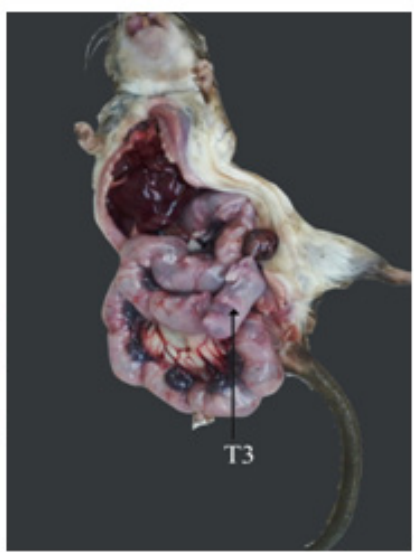

Late trimester

Figure 2 Embryonic stages of Bandicota indica (in situ).

Trimester 3 (T3): The duration of trimester 3 ranged from 7-8 days. In early stage of T3, eyes, ears and tail became obvious. Limbs appeared with fingers and toes (Figure $2 \mathrm{E}$ ). In late stage of T3, blood circulation system became visible through the pale skin and the embryo look like adult form without hairs. The length of embryo ranged from 20-35 mm (Figure 2) (Table $1 \& 2$ ).

\section{Discussion}

The present study area embodied Magway, Minbu (Sagu), Pwintbyu and Kamma Townships in the Magway Region, mostly cultivated paddy, cereal grains and legumes. Greater Banticoot rat caused damage to the crops annually in this area. Their burrowing habits and feeding on grain cause great damage to cultivated fields and thus represented. Therefore it was a very serious pest in the study area. The food consumption of Bandicoot rat on a variety of cereal grains and legumes. ${ }^{8}$ The greater bandicoot rat is the largest murine rodent that occurs in the rice fields in Thailand. They build underground nests in burrows in levee bank between the rice fields. ${ }^{9}$ The bandicoot rat in the genus Bandicota are predominant in rice fields in Thailand. Thus murine species caused considerable damage to the rice crops and leading to considerable economic loss to the country. ${ }^{10}$ In present study, the monthly sex ratio of $B$. indica did not deviated significantly from 1:1 in April and November. Generally male slightly increased in the sex ratio in the remaining months. According to $\chi^{2}$ test, the seasonal sex ratio was not significantly difference between male and female $\left(\chi^{2}=1.19 ; \mathrm{p}>0.05\right)$. However, slight increase in the number of female was observed in March and July. It is assumed that males of $B$. indica were more active than females and hence fall prey to trapping than females or that increased mortality due to predation by different predators. People who live in present study area said that the highest population was observed in harvesting time of crop. In present result, the peak abundance of rats in the field was recorded to coincide with the harvest time of rice and alluded to abundance availability of food sources during these period and the favorable weather condition caused this species to appear in large number at that time, indicating that Bandicoot rat population peaked with the abundance availability of food sources. The pregnant females $B$. indica were found throughout the year. The mean litter size of $B$. indica was highest in September. The right uterine horn harboured more embryo than left and the average number of embryos ranged from 6.1 to 8.62 in $B$. indica. The mean litter size of $B$. indica was 5.0 in the laboratory and 5.3 in the wild. ${ }^{11}$ In present study the higher reproduction potential was found in rainy season (14.9 young/ female/ season) and cold season (12.3young/ female/ season) than hot season.

\section{Conclusion}

The maximum reproductive activity of $B$. indica coincided with occurrence of the wet season during two year study in rice field of southern Thailand. ${ }^{11}$ Thus they suggested that the greater reproductive output of the population occurred during the in wet than in the dry season. The breeding of $B$. indica coincided with generative stages of rice crop occurred during the booting stage of rice plant production. Therefore, rapidly multiplying rodent populations can wreak havoc on crops and foodstuffs. There is need to work out effective control methods to keep the rodents populations under check, in order to safeguard the harvest yield. 


\section{Acknowledgments}

None.

\section{Conflicts of interest}

Author declares that there is no conflicts of interest.

\section{References}

1. Grzimek B. Grzimek's animal life encyclopedia. $2^{\text {nd }}$ edn. 2004.

2. Aplin KP, Brown PR, Jacob J, et al. Field method for rodent studies in Asia and the Indo-Pacific. Australian Centre for International Agricultural Research: Canberra. 2003;1-223.

3. Skonhoft A, Leirs H, Andreassen HP, et al. The Bioeconomics of Controlling an African Rodent Pest Species. Environment and Development Economics. 2006;11:435-475.

4. Sarwar M, Ashfaq M, Baig M. The Species Complex, Damage Pattern and Control of Rodents (Mammalia: Rodentia) in Sugarcane (Saccharum officinarum L.) Fields. International Journal of Agronomy and Plant Production. 2011;2(4):145-150.
5. Fayenuwo JO, Olakojo SA, Akande M, et al. Comparative evaluation of vertebrate pest damage on some newly developed quality protein maize (QPM) varieties in South Western Nigeria. Afri J Agric Res. 2007;2(11):592-595.

6. Singleton GR. Impact of Rodents on Rice Production in Asia. Philippines: International Rice Research Institute; 2003.

7. Beg MA, Mushtaqul Hassan M, Durri Shahwar, et al. The dynamic of Rats and Mice Populations Inhabiting Wheat Sugarcane Based Croplands in Central Punjab (Pakistan). Pakistan J Zool. 2010;42(3):311-323.

8. Sagar P, Bindra OS. Food and feeding habits of the lesser bandicoot rat. Pest Control. 1976;12:28.

9. Thitipramote N, Suwanjarat J, Breed WG. Reproductive biology of the greater bandicoot rat Bandicota indica (Rodentia: Muridae) in the rice fields of southern Thalaid. Curr J Zool. 2009;55(1):48-55.

10. Boonsong P, Hongnark S, Suasaard, et al. Rodent management in Thailand. In: Ecologically based Management of Rodent Pests. Singleton GR, Hinds LA, Leirs H, Zhang Z, editors. 1999;338-358.

11. Lam YM. Some Aspects of the Reproduction, Growth and Development of Bandicota indica in Captivity. Mardi Res Bull. 1985;13(3):207-217. 